\title{
Ergenlerde Akran Zorbalığını Yordayan Bazı Faktörlerin Zorba ve Mağdur Bireyler Açısından Değerlendirilmesi ${ }^{1}$
}

\author{
DOI: 10.26466/opus.543567
}

Nurullah Yelboğa ${ }^{*}$ - Orhan Koçak**

* Öğr. Gör., Artvin Çoruh Üniversitesi, Borçka Acarlar M.Y.O, Sosyal Hizmetler, Artvin / Türkiye E-Posta: nurullah yel06@hotmail.com

ORCID: 0000-0001-8281-7070

${ }^{* *}$ Doç. Dr., İstanbul Üniversitesi, Sağlık Bilimleri Fak., Sosyal Hizmet Bölümü, İstanbul / Türkiye

E-Posta: orkoc@hotmail.com

ORCID: 0000-0002-0281-8805

Öz

Ergenlik dönemine ilişkin sorunlar tarihsel süreç içerisinde her ne kadar farklllk göstersede tüm toplumlarda günümüze kadar var olmaya devam etmiştir. Çünkü ergenler bu dönemde kimlik oluşumunu yaşamakta, geleceği planlamakta ve son derece zor bir süreçten geçmektedir. Dost edinme ve arkadaşlık kurmanın önem kazanması, popülerlik, kendini gerçekleştirme, hedefler belirleme ve en önemlisi çok hızlı biyo-psiko-sosyal değişimler geçirmesi bu bireyleri farklı problemler sarmalına sürükleyebilmektedir. Dolayısıyla gençlerin bu problemler karşısında gösterdiği tepkiler bazen aşırıya varmakta ve şiddet davranışlarında artışlar görülebilmektedir. Saldırganlı̆̆ın bir türü olan zorbalı̆̆ın, bireylerin kendi hedeflerine ulaşmak, otorite kurmak ve karşı tarafı yıldırmak gibi amaçlarla kullanıldığı bilinmektedir. Saldırganlı olaylarının son yıllarda hem dünyada hem ülkemizde yaygınlaşması bu konuya eğilimi beraberinde getirmiştir. Bu çalı̧mada akran zorbalı̆̆ olgusu irdelenmiş ve zorbalığı etkileyen yaş, cinsiyet, fiziksel özellikler, kişilik özellikleri ve ebeveyn tutumları gibi bazı faktörlerin zorbalık davranışı ile ilişkisi incelenmiştir. Ayrıca makalede akran zorbahı̆̆ının ergenler üzerindeki etkilerine yer verilmiş ve ulaşılan bilgiler dikkate alnarak birey, aile ve okul yönetimini kapsayan önerilerde bulunulmuştur.

Anahtar Kelimeler: Zorbalık, Akran zorbalı̆̆ı, Saldırganlık, Şiddet, Ergenlik

\footnotetext{
${ }^{1}$ Bu çalışma "Liseli Öğrencileri Akran Zorbalığına iten Nedenlerin Değerlendirilmesi ve Okul Sosyal Hizmeti Bağlamında Çözüm Önerilerinin Sunulması” adlı yüksek lisans tezinden yararlanılarak oluşturulmuştur
} 


\title{
Evaluation of Some Factors Predicting Peer Bullying in Adolescents
}

\begin{abstract}
Although the problems related to adolescence have changed in the historical process, they have continued to exist in all societies to the present day. Because adolescents are experiencing identity formation, planning the future and going through a very difficult process. The importance of friendship and friendship, popularity, self-realization, setting goals, and most importantly, having very rapid bio-psycho-social changes, can lead these individuals to the coherence of different problems. Therefore, the reactions of young people towards these problems are sometimes overpowered and violent behaviors can be seen. It is known that bullying, which is a form of aggression, is used for individuals to achieve their goals, establish authority and intimidate the other party. In recent years, the spread of aggression events both in the world and in our country has led to this issue. In this study, the phenomenon of peer bullying was examined and the relationship between bullying behavior and some factors such as age, gender, physical characteristics, personality traits and parental attitudes were examined. In addition, the effects of peer bullying on adolescents were included in the article and suggestions were made regarding the individual, family and school management by considering the information obtained.
\end{abstract}

Keywords: Bullying, Peer bullying, Aggression, Violence, Adolescence. 


\section{Giriş}

İnsan gelişim dönemleri içerisinde önemli bir evre olan çocukluk çağında, birçok çocuk açlıkla savaşmakta, suça itilmekte, eğitim ve sağlık haklarından yeterince yararlanamamakta ve ölüme sürüklenmektedir. Günümüzde dünyada ve Türkiye'de çocukların yaşamını tehdit eden savaş, göç, madde kullanımı, şiddet ve zorbalık gibi birçok konu bulunmaktadır. Ergenlik döneminin beraberinde getirdiği bilişsel, sosyal ve duygusal açıdan hızlı gelişim ve değişim de bireyin karşılaştığı bu sorunların etkisini derinleştirebilmektedir.

Zorbalık olaylarının çocuklar arasında görülme durumu çok eski tarihlere dayanmaktadır. Söz konusu olayları birçok birey bizzat yaşamış veya başka çocuklara uygulanan saldırgan davranışlara tanıklık etmiştir. Hatta bazı çocukların diğer bazı çocuklara sistematik olarak saldırganca davranması ve acımasizca davranmaya zorlanması edebi eserlerde ve filmlerde yer edinmiştir (Dölek, 2002, s.25). Bununla birlikte insanlığın çağlar boyu tartışmasız anlaştığı belki de tek konu çocukların toplumun geleceği olduğu gerçeğidir. İnsan, sevgisini hiç sakınmadan çocuklara vermiş, en güzel düşleri onlar için kurmuş ve yaşanası bir dünyayı çocuklar için istemiştir. Ne var ki, bu uğurda verilen nice savaşıma, nice uğraşıya karşın çocukların yüzleştiği sorunlar tüm ağırlığıyla var olmaya devam etmiştir (Yavuzer, 2016, s.11). Son zamanlarda yapılan araştırmaların sonuçları ve medyada çıkan haberler incelendiğinde, tüm önlemlere karşın çocuk ve ergenlik dönemindeki bireyler arasında şiddet ve suç olaylarının artış gösterdiği dikkati çekmektedir (Buluç, 2006, s.1; akt. Eşici, 2007, s.30). Söz konusu bu sorunlar çocuk ve ergenlerin birçok yönden potansiyellerini gerçekleştirmelerine, özgür ve sağlıklı bir yaşam sürdürmelerine, sosyal yaşama ve etkinliklere katılımlarına engel olmaktadır. Bununla birlikte özgüven ve benlik saygıları bu sorunlardan olumsuz etkilenmekte ve bu bireyler depresyona sürüklenebilmektedir. 


\section{Araştırmanın Tanımlayıcı Çerçevesi}

\section{Araştırmanın Problemi}

Akran zorbalığı zorbalık olaylarına karışan tüm bireyler açısından travmatik sonuçlar doğuran ve etkileri uzun döneme yayılan karmaşık bir problemdir. Okullarda şiddet, zorbalık ve saldırganlık gibi başlıklarla bu konu birçok araştırmacı tarafından incelenmiştir. Bu araştırmaların bir kısmı eğitim ve öğretim ortamlarını olumsuz etkileyen sorunları analiz etmek ve olumsuz okul iklimine açıklık getirmek için yapılmıştır. Bu çalışmada ise "akran zorbalığını tetikleyen yaş, cinsiyet, fiziksel özellikler, aile özellikleri, sosyo-ekonomik durum, psikolojik ve davranışsal özellikler gibi faktörlerin zorba ve mağdurlar açısından nasıl bir etkiye sahip olduğu" anlaşılmaya çalışılmıştır.

\section{Araştırmanın Amacı}

Akran zorbalığı, çocukların eğitim yaşamını, başarılarını ve okula bağll1ıklarını olumsuz yönde etkileyen, stress, depresyon, düşük özgüven gibi psikolojik; suça karışma ve yalnızlaşma gibi bazı sosyal sonuçlar doğuran bir sorundur. Özellikle devamsızlık ve akademik başarının düşmesi gibi durumlarda daha açık bir şekilde etkisi fark edilen bu sorun aileleri, yöneticileri, öğretmenleri ve zorbalığa karışan çocukları tedirgin etmektedir. Bu açıdan bakıldığında söz konusu sorunun kalıcı bir şekilde çözülmesi için öncelikle sorunu yordayan faktörlerin iyi bir şekilde analiz edilmesi gerekmektedir. Bu bağlamda çalışmanın amacını, önleyici ve koruyucu tedbirlerin alınması ve mevcut sorunun etkin çözümü için bireysel, sosyal ve çevresel özelliklerin sürece dahil edilmesi ve sorunun daha derinlikli bir okumasının yapılması oluşturmaktadır. Bu amaç doğrultusunda önce "akran zorbalı̆̆ı" tanımlanmış, zorbalığın nedenleri irdelenmiş, zorbalığın sonuçları tartışılmış ve daha sonra ise zorbalıkla ilişkilendirilen yaş, cinsiyet, kişilik özellikleri ve aile özellikleri gibi bazı faktörler akran zorbalığı çerçevesinde açıklanmaya çalışılmıştır. 


\section{Ergenlik}

Alan yazında ergenlik dönemi ile ilgili bir çok tanımlama bulunmaktadır. Ergenliği Türk Dil Kurumu (20.10.2017) “cinsel organların fizyolojik gelişmesiyle başlayan, büluğa ermişlikle yetişkinlik arasındaki dönem, yeni yetmelik, ergenlik çağı" olarak tanımlanmaktadır.

Ergenlik sözcüğü Latince'de büyümek, kıllanmak, olgunlaşmak anlamındadır. Bu dönem yoğun ve hızlı bir biyo-psiko-sosyal değişimin söz konusu olduğu, bireyin geleceği ile ilgili plan yaptığı ve sosyal çevresinde kendine yer edinmeye çalıştığı bir süreçtir (Eskin vd., 2008, s.383). Benzer şekilde Steinberg $(2007$, s.21) de ergenliğin Latin kökenli bir kelime olduğunu "yetişkinliğe doğru büyüyen" anlamındaki adolescere yükleminden türediğini ve bütün toplumlarda çocukluğun olgunlaşmamışlığından yetişkinin olgunluğuna yani biyolojik, psikolojik, toplumsal ve ekonomik geçişin gerçekleştiği bir dönem olduğunu belirtmektedir.

Çocukluğun ayrı bir dönem mi yoksa ergenlik dönemi içerisinde ele alınan bir evre mi olduğu da tartışılmaktadır. Yavuzer (2016, s.30) "çocuk" sözcügüule henüz reşit olmamış ergenlerin kastedildiğini ve yaş aralığının 11-18 yaş grubu olduğunu ifade etmektedir. 14 yaş grubunun hem bazı Avrupa ülkelerinde hem de ülkemizde en çok suç işlenen yaş olduğunu, bu dönemin "problemli evre" ya da "geçiş evresi" olarak nitelendirildiğini ve ergenlik dönemine rastladığını vurgulamaktadır. "Ben kimim?", "Kime benzemeliyim?", "Başkalarma nasıl görünmeliyim?" gibi sorulara yanıt arandığını ve çocukluktan yetişkinliğe geçiş dönemine denk geldiğini belirtmektedir.

Ergenlik dönemi üzerine çalışan psikolog Sullivan da ergenliği üç aşamada açıklamaktadır. İlk aşama ön ergenlik dönemi olup; çocukluktan ergenliğe geçişin ilk basamağını oluşturmaktadır. Bu dönemde arkadaş edinme davranışı ve her iki cinsten kişilerle ilişkiler kurma yoluyla sosyokültürel bir çevre oluşturulmaktadır. İkinci aşama ise; genç ergenlik dönemidir. Bazı temel ihtiyaçların karşılandığı ve cinsel anlamda bir olgunluğun görüldüğü aşamadır. Son aşama ise genç ergenlik dönemi olup; cinsel davranış kalıplarının belirlendiği ve bu sürecin yaşamının geri kalan kısmına nasıl yansıyacağına dair bir fikrin oluştuğu dönemdir (Yaman, 2016, s.48). 
Bu dönemde meydana gelen değişimlerden, ergenlerin çoğu zaman rahatsızlık duyduğunu ve stres yaşadığını belirtmek gerekir. Bu sebeple G. Stanley Hall de ergenlik dönemini "fırtınalı ve stresli" bir süreç olarak nitelendirmektedir. Ona göre ergenlik yeniden doğmak kadar sancılı bir dönemdir (Dinçel, 2006, s.12; Uysal, 2003, s.31). Rutter da (1976) aynı görüşü desteklemekte ve ergenin iç dünyasında bazı rahatsızlıklar geçirmekte olduğunu ve çevresinin de bunu fark etmediğini belirtmektedir. Bu sebeple Parman (1998) de ergenliği ikinci kez doğmak olarak değerlendirmektedir.

\section{Zorbalığın Tanımı ve Kapsamı}

Olweus zorbalıktan söz edebilmemiz için, bir veya birden fazla kişinin sürekli ve uzun bir süre boyunca diğer bir kişiye acı veren ve hoş olmayan davranışta bulunması gerektiğini belirtmektedir. Ona göre acı ve hoşnutsuzluk meydana getiren tekme, vurma, hakaret, şantaj ve tehditler doğrudan zorbalık kapsamına girmektedir. Sistematik bir şekilde devam eden alay etme de bu kapsamda değerlendirilmektedir. Dolaylı zorbalık ise dışlama, bireyin bir gruba dahil olmasını engelleme ve arkadaş edinmesine engel olmaya karşılık gelmektedir. Bu gibi durumlar da bireyde aynı acı ve üzüntüye sebep olabilmektedir (Olweus ve Solberg, s.7).

Roland (1989) da zorbalık için "Bir birey veya grup tarafindan kendisini koruyamayacak durumda olan kişiye karşı yapılan fiziksel veya psikolojik sonuçları olan ve süreklilik arzeden şiddet türüdür." (Roland, 1989; akt. Pişkin, 2002, s.535) demektedir.

Zorbalıkla ilgilenen ilk araştırmacı Heinemann (1973, akt. Yaman vd., 2011, s.13) zorbalığ1 tanımlamak için mobbing sözcüğünü kullanmıştır. Okul zorbalığı için de "grup şiddeti"ni kullanmıştır. Heinemann bir grubun başka bir birey tarafından rahatsız edilmesine dayandırarak grup tarafından gösterilen tepkinin grubu savunmaya yönelik olduğunu belirtmiştir. Heinemann'a göre grubun böyle bir tepki göstermesinin nedeni kendi bütünlügünü korumaya çalışmasıdır. Olweus (1978, akt. Yaman vd., 2011, s.13) da zorbalık için başlangıçta mobbing kelimesini kullanmış ancak daha sonra okul zorbalığı için "bullying" kelimesini uygun görmüştür. Çünkü mobbing teriminin bu olgu için yeterli olmadığını fark etmiştir. 
Bonds ve Stoker (2000, akt. Anderson, 2007, s.37) kavga eden taraflardan biri, karşı tarafın bundan rahatsızlık duyduğunu fark eder ve otorite kurmak için bunu sürekli olarak kullanmayı sürdürürse bunun zorbalık olarak nitelendirilmesi gerektiğini ifade etmiştir. Ancak bu durumda da güç dengesinin ölçüt olarak kabul edilmesi gerektiğini vurgulamıştır.

Bir davranışın zorbalık olarak kabul edilmesi için Olweus (1978)' a göre şu üç kriteri taşıması gerekmektedir:

- Bilinçli olarak zarar vermeye yönelik bir amaç,

- Süreklilik arz etmesi,

- Zorba ve mağdurun psikolojik ya da fiziksel açıdan denk olmaması (Yaman vd., 2011, s.13-14; Başaran, 2014, s.11).

Colorosso $(2003,2005,2009,2013)$ da bir eylemin zorbalık sayılması için dört kriter belirlemiştir.

- Güç dengesizliği: Zorba, kurbana ya da mağdura göre yaş ya da fiziksel olarak daha büyük ve güçlüdür.

- Zarar verme isteği: Zorba kurbana zarar vermek istemekte ve bundan keyif almaktadır.

- Saldırganlık tehdidi: Zorba bu davranışın devam etme isteğindedir ve kurban da bunun farkındadır.

- Korkutma: Mağdur üzerinde bir baskı kurmak ve mağduru aşağ1lamak için korkutma amacı vardır (http://www.kidsareworthit.com/services.html, 12.12.2017).

$\mathrm{Bu}$ tanımlar dikkate alındığında zorbalığın güç dengesizliğine dayandığı, otorite kurmaya yönelik sistematik bir şekilde süreklilik arz eden davranışları barındırdığı görülmektedir. Zorbalığın tanımı yapıldıktan sonra zorbaların neden zorbaca davrandığı ve bu davranışın altında hangi nedenlerin yer aldığına bakmakta yarar vardır.

\section{Zorbalığın Nedenleri}

Zorbalık davranışının nedenlerini açıklarken Olweus (1987; akt. Genç, 2007, s.20) zorba davranışında kişilik özellikleri ve cinsiyetin etkili olduğunu vurgulamıştır. Güçlü enerji ve sinirli yapı gibi nitelikleri taşıyan çocukların zorbalığa daha yatkın olduklarını ifade etmiştir. Zaklama (2003, s.35-38) da zorbalığın nedeni olarak aile yapısını işaret etmekte ve zorbalığa başvuran öğrencilerin genellikle ailede sert cezalara maruz 
kaldıkları ve sevgisiz bir ortamda yetiştiklerini belirtmektedir. Sert bir şekilde anne babanın tepkisiyle karşılaşan çocukların bu davranışları dışarıda arkadaş ve çevrelerine sergiledikleri bildirilmektedir.

Olweus (1987; akt. Genç, 2007, s.20) çocukların yaş, cinsiyet ve farklı kişilik yapıları gibi özelliklerin zorbalık davranışında etkili olduğunu belirtmiştir. Bununla birlikte evde çocuk bakımını veren kişi ile çocuk arasındaki ilişkiye de dikkati çekmiştir. Zaklama (2003) ve Genç (2007) de evdeki ilişkilere ve ailedeki saldırgan davranışlara ve şiddete dikkati çekmektedir (Genç, 2007, s.20; Zaklama, 2003, s.35-38).

Ayrıca Olweus (1995; akt. Gökler, 2009, s.526) zorbalık davranışının altında yatan birbiriyle kısmen ilişkili üç psikolojik faktör belirlemiştir:

1. Zorbaların güç ve baskınlık kurmaya yönelik güçlü gereksinimleri vardir.

2. Arka plana itilmiş ailelerde yetişmişlerdir ve bunun bir sonucu olarak, çevreye karşı nefret duyguları içerisindedirler.

3. Zorbaca davranışlarının araçsal bileşenleri ya da getirileri vardır: Örneğin zorbalar, kurbanlarını para, sigara, bira gibi kendileri için değerli olan şeyleri temin etmeleri için zorlarlar.

Diğer taraftan teknolojik araçlarla iç içe bir yaşam sürdüren çocukların bu araçlar yoluyla şiddete sürekli tanıklık etmeleri şiddet eylemini normalleştirmektedir. Televizyon dizileri, telefon ve internet oyunları, video ve müzik gibi eğlence araçları vasıtasıyla şiddet ve saldırganlık eylemiyle ilişkileri olan çocuklar bu davranışın uygulayıcıları haline gelebilmektedir (Genç, 2007, s.20).

Zorbaca davranmaya sebep olan durumların belirlenmesinde farklı problemlere işaret edilmektedir. Şekil 1'de zorbalığı ortaya çıaran nedenlere ilişkin davranışlar belirtilmiştir (Kılıç, 2009, s.22). 


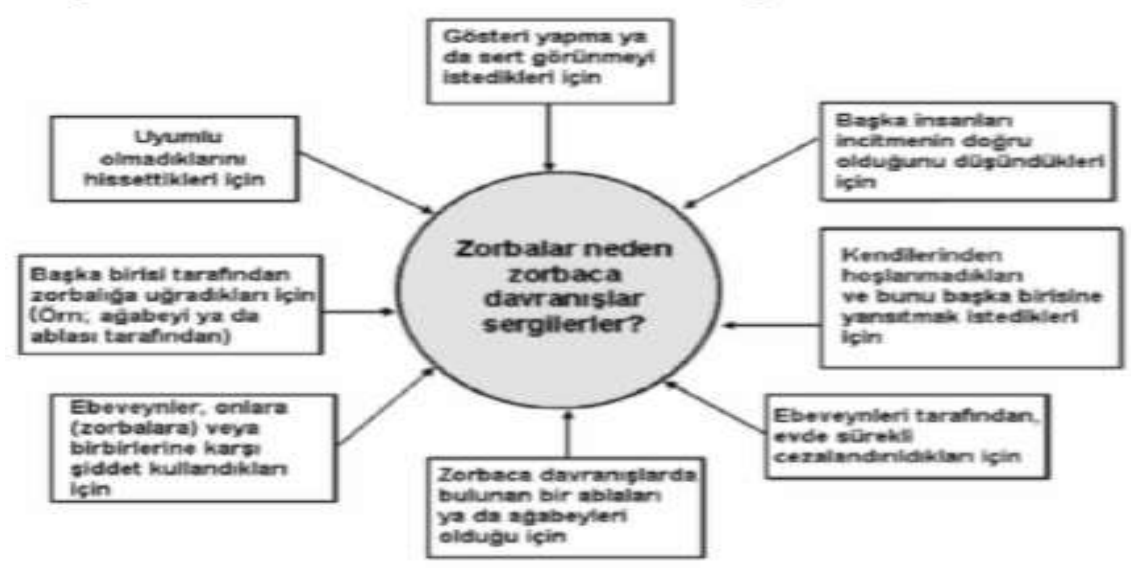

Şekil 1. Zorbalar Neden Zorbaca Davranışta Bulunurlar

Zorbalığa neden olan faktörler olduğu gibi çocukların kurban seçilmesinde etkili olan faktörler de bulunmaktadır. Amerikan Pediatri Akademisi (2006) ve Birleşik Devletler Sağlık ve İnsan Hizmetleri Ofisi kurbanı zorbaca davranışa hedef haline getiren, çocukları zorbalığa karşı mağdur duruma düşüren risk faktörlerini şu şekilde belirtmiştir (Huggins, 2016, s.175-176):

- Görünüşte akranlarından farklı olan; kilo, giyim, saç şekli ve gözlüklü olmak gibi,

- Zayıf olan veya kendilerini savunmada yetersiz kalan,

- Depresyonda, üzgün, kaygilı görünen veya özgüveni düşük olan,

- Soyutlanan veya çok az arkadaşı olan,

- Sosyal davranışlarda yetersiz kalan veya kolay karıştıran,

- Gelişimsel veya fiziksel yetersizliği olan çocuklar.

\section{Zorbalığın Sonuçları}

Zorbalık olaylarına karışmanın sonuçlarını inceleyen bazı araştırmalar olumsuz zihinsel ve fiziksel sağlık sonuçlarına odaklanmıştır. Söz konusu bu olumsuz koşullar dört kategoriye ayrılmıştır (Rigby, 2003, s.583):

1. Düşük psikolojik iyilik hali. Genel hoşnutsuzluk, düşük benlik sayg1sı, öfke ve hüzün duyguları gibi ciddi bir şekilde acı veren durumlar. 
2. Zayıf sosyal uyum. Bu, normalde, bir sosyal çevreye isteksizlik duygusunu, okul ya da işyeri için açıkça belirtilmeyen hoşnutsuzluk, açıkça görülen yalnızlık, soyutlama ve devamsızlığı içerir.

3. Psikolojik sıkıntı/kaygı. İlk iki kategoriden daha ciddi olduğu düşünülen yüksek derecede anksiyete, depresyon ve intihar düşüncesini içerir.

4. Fiziksel rahatsızlık. Açıç̧a görülen ve tıbben teşhis edilen fiziksel bozukluklar ve belirtileri içerir. Psikosomatik semptomlar da bu kapsamda değerlendirilir.

Ancak zorbalık olaylarının uzun dönemli etkilerini inceleyen araştırmalar da yaygındır (Isernhagen ve Harris, 2002, s.7; Craig, vd., 1998, s.7). Kısa dönemli etkilerinin yanında zorba çocuklar yetişkinlik döneminde zorba olabilmekte ve zorba çocuklara sahip olabilmektedir. Benzer şekilde mağdur/kurban çocuklar da ileriki yaşamlarında mağdur olan çocuklara sahip olabilmektedirler. Çünkü boylamsal araştırmalar çocukluk dönemindeki zorbalığı yetişkinlik dönemindeki suçluluk gibi antisosyal davranışlarla ilişkilendirmektedir (Craig, vd., 1998, s.7). Zorba-kurbanların düşük özsaygı, artan devamsızlık ve depresyon gibi sorunlar yaşadıkları görülmekte ve zorbalığa yakalanma olasılıkları daha yüksek olmaktadır. Ayrıca çocukların sosyal ve kişisel gelişimi sosyal yalıtıma neden olabilir, okuldan ayrılmayı teşvik edebilir ve öğrenme kapasitelerini düşürebilir (Jody ve Harris, 2002, s.7).

Davranışsal yönden de zorbalığın etkileri olduğu düşünülmektedir. Zorbalık olaylarına karışan öğrencilerin karışmayanlara göre daha çok kendine zarar verici davranışta bulunduğu belirlenmiştir. Alkol-tütün kullanımı, kavgaya karışma gibi davranışların sergilenmesine yönelik bir eğilim söz konusu olmaktadır. Kopya çekmek, hırsızlık yapmak, yıkıcı eylemlerde bulunmak, polislerle sorun yaşamak ve okulu asmak ile zorbaca davranma arasında önemli ilişki olduğu vurgulanmaktadır (Dake, vd., 2003, s.174).

Görüldüğü gibi zorbalık davranışının yönü, boyutu ve sonuçları zorba ve mağdur bireylerin bazı özelliklerine göre değişmektedir. Konunun daha iyi anlaşılması açısından aşağıda zorbalığı açıklayan kuramlara yer verilmiştir. 


\section{Zorbalığa İlişkin Kuramlar}

Zorbaca davranma nedenlerini açılamaya yönelik kuramlar geliştirilmiştir. Zorbalığı önlemeye yönelik üzerinde sıklıkla durulan Sosyal Bilgiyi İşleme Kuramı ve Zihinsel Çerçeve Kuramı'dır. Zorbalığı açıklamaya yönelik diğer bazı kuramlar ise Ahlaki Gelişim Kuramı ve Sosyo-Ekolojik Yaklaşım kuramlarıdır (Yaman vd., 2011, s.141).

Sosyal Bilgiyi İşleme Kuramı: Crick ve Dodge (1994) tarafından geliştirilen (Yaman vd., 2011, 142-143) bu modelde bireylerin davranışsal tepkilerinin girilen ortamda elde edilen ip uçlarına göre şekillendiği savunulmaktadır. Ayrıca sosyal ortamda verilen tepkilerin aslında doğuştan getirilen özellikler ve geçmiş yaşamla yakından ilişkili olduğu varsayılmaktadır. $\mathrm{Bu}$ modele göre sosyal ortama girildikten sonra ipuçlarının davranışa dönüştürülme süreci 4 aşamada gerçekleşmektedir. Bunlar; durumsal ipuçlarının yorumlanması, ipuçlarının temsil edilmesi, zihinsel anlamda duruma verilecek tepkilerin araştırılması ve uygun tepkinin seçilmesidir.

Zihinsel Çerçeve Kuramı: "Bireyin herhangi bir ortamda kendisinin ve diğer bireylerin davranışlarım anlayabilmek ve iletişim kurduğu bireylerin göstereceği davranışlar tahmin edebilmek için bilişsel şemaları kullanabilme yeteneği $i^{\prime \prime}$ şeklinde tanımlanmaktadır (Yaman vd., 2011, s.145). Bu kuramın savunucuları olan Sutton ve diğerleri (1999, s.443-444) yaptıkları çalışmada sosyal bilişsel puan ile zorba davranışı arasında önemli bir ilişki bulmuşlardır. Diğer bir ifadeyle zorbaların puanı zorbalık sürecinde rol alan diğer bireylerin puanından daha yüksek çıkmıştır. Bu çalışmaya göre zorbalar diğer bireylerin duyguların daha iyi anlamakta ancak bu beceriyi kendi çıkarları doğrultusunda kullanmaktadırlar.

Ahlaki Gelişim Kuramı: Ahlaki gelişim dört aşamada gerçekleşir. Birincisi, ahlaki duyarlılıktır; ahlaki bir problem olduğunun farkına varmayı içerir. İkincisi, ahlaki yargılamadır; ahlaki açıdan en uygun davranışın ne olduğunu sorgular. Üçüncüsü, ahlaki güdülemedir; davranışla ortaya konulmak istenen ahlaki değerlerin belirlenmesini ifade eder. Dördüncüsü, ahlaki kişilik; bireyin davranışı ortaya koyabilmek için gerekli azim ve becerileri kapsar (Yaman vd., 2011, s.148). Bu kuramda göre, bireyler eylemden önce davranışın yol açacağı bütün olası sonuçları değerlendirerek en uygun davranışın ne olacağını belirlemeyi sağlayan bilişsel 
karar verme yetisine sahiptir. Dolayısıyla zorbalığın anlaşılabilmesi için ahlaki gelişim düzeylerinin dikkate alınması gerektiğini vurgulamaktadır (Nurseli, 2014, s.54).

Sosyo-Ekolojik Yaklaşım: Zorbalığın, birey, aile, akran grubu, okul ve toplum arasındaki karşılıklı etkileşim sonucu ortaya çıktığını ileri sürmektedir. Bu sebeple okul zorbalığının önlenebilmesi için okul zorbalığına yol açan bireysel özelliklerle birlikte okul iklimi, aile içi ilişkiler ve kültürel etmenler gibi sosyo-çevresel etmenlerin de iyileştirilmesi gerektiğini varsaymaktadır ( Yaman vd., 2011, s.149; Nurseli, 2014, s.54).

Birçok konuda olduğu gibi zorbalık kuram ve yaklaşımlarında da farklı sinıflandırmalar söz konusu olmaktadır. Bu sebeple yukarıda açıklanan kuramların yanı sıra ele alınması gereken başka kuramlar da bulunmaktadır. Saldırganlık davranışlarının daha net anlaşılabilmesi için “Sosyal Öğrenme Kuramı”nın açıklanmasında yarar vardır.

Sosyal Öğrenme Kuramı: Başkalarının davranışları ve bu davranışların gözlemlenmesine dayalı dolaylı bir öğrenme olarak kabul edilmektedir. Model alarak öğrenme; model alma (modeling), gözlemleyerek öğrenme (observational learning), taklit (imitation), özdeşleşme (identification), içselleştirme (internalization) gibi terimlerle açıklanmaktadır. Burada en belirleyici faktör bireyin başkalarını gözlemleyerek öğrenmesidir (Demirbaş ve Yağbasan, 2005, s.367).

Sosyal Öğrenme Kuramı'nın prensiplerini ilk defa belirleyen Bandura ve Walters (1994; akt. Kaya, 2009, s.31) içgüdüsel dürtülerin ve engellenmiş saldırganlık dürtülerinin insan saldırganlığının sebebi olamayacağını açıklamıştır. Bandura'ya göre kişilerin diğerlerine saldırganca davranmasının sebepleri şu şekildedir :

- Geçmiş deneyimlerin sebep olduğu saldırgan tepkiler,

- Gösterdikleri davranışlar sonucunda ödüllendirilmiş olmaları veya ödüllendirileceklerini düşünmeleri,

- Saldırganlığa özel, sosyal veya çevresel şartlar yoluyla doğrudan teşvik edilmeleri.

Bu modele göre saldırgan davranışlar gözlem yoluyla edinilmekte ve ceza/ödül yöntemiyle sürdürülmektedir. 
$\mathrm{Bu}$ teoriye göre başkaları gözlemlenerek bilgi aktarılır ve davranışlar model alınır. Gözlem sonucunda model alınan kişilere bağlı olarak duyuşsal ve davranışsal özellikler değişebilmektedir. Model alarak öğrenme süreci Şekil 2' de aşamalı olarak verilmiştir (Demirbaş ve Yağbasan, 2005, s.368).

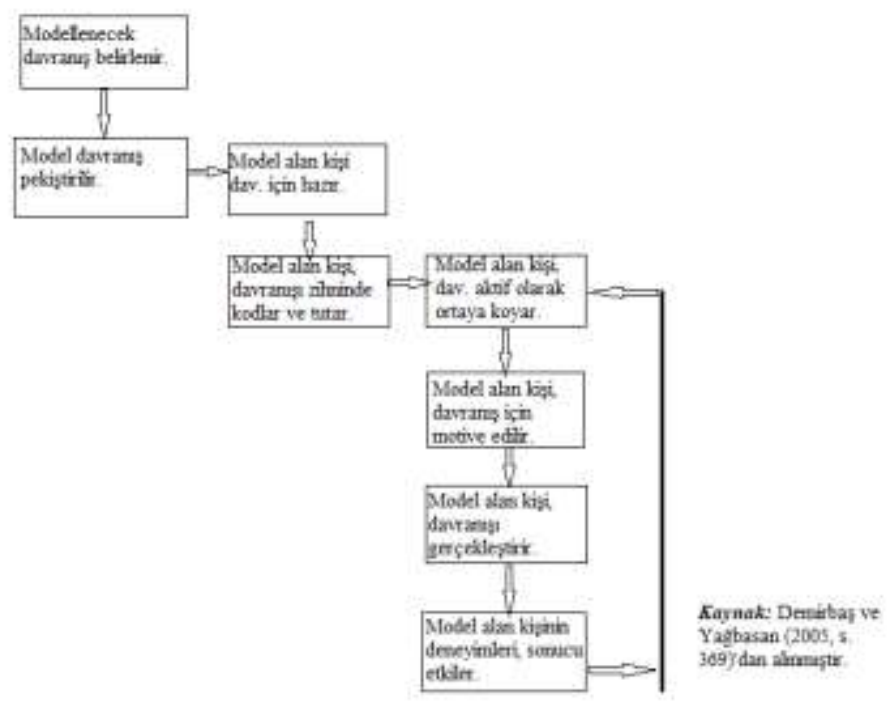

Şekil 2: Model Alma İle Öğrenme Aşamaları

Söz konusu kuramlar birlikte değerlendirildiğinde, zorbalığın hem nasıl geliştiği hem de hangi koşullar altında öğrenildiği daha net anlaşılmaktadır. Bu kuramlar sosyal ortamlara, duyguların anlamlandırılmasına, model alarak öğrenmeye, bireysel ve aile özellikleriyle birlikte çevresel faktörlere dikkati çekmektedir. Ayrıca söz konusu kuram ve yaklaşımlar bize zorbalık davranışının daha doğru okunması ve analiz edilmesi için hem bir çerçeve çizmekte hem de çözüme yönelik nasıl bir yol izlenebileceği ve hangi yollarla müdahale edilebileceği konusunda aydınlatıcı bilgiler sunmaktadır. Zorbalıkla ilgili kuram ve yaklaşımlar kısaca açıklandıktan sonra araştırmanın ana temasını oluşturan ve zorbalığın yordayıcıları olarak nitelendirilebilecek faktörlerin zorba ve mağdur bireyler açısından incelenmesi konunun daha iyi anlaşılması açısından büyük önem arz etmektedir. 


\section{Zorba Ve Mağdurların Çeşitli Değişkenlere Göre Değerlendirilmesi}

\section{Yaş}

Literatürde yaş frekansı ile zorbalık davranışı arasındaki ilişkinin sıkça irdelendiği görülmektedir. Örneğin Salmivalli (2002, s.275-276)'nin çalışmasında kullanılan kişisel raporlarda yaş arttıkça hedef olma frekansının düştüğü belirtilmektedir. Başka bir ifadeyle daha küçük yaş grubundakiler mağdur olmayı daha çok deneyimlemektedir. Ancak bu araştırmada kurbanların akranları söz konusu zorbalığın yaşanmadığını düşünmektedir. Diğer bir ifadeyle küçük çocuklar zorbalığa daha çok maruz kalabilmekte ancak akranları bu durumun farkına varamamaktadır.

Literatür taraması sonucunda yaşın zorbalık davranışı üzerinde etkili olduğu, bazı araştırmalarda yaşla birlikte zorbalık sıklığının arttığı buna karşın kurban olma sıklığının azaldığı ortaya çıkmaktadır. Diğer taraftan yaşla beraber zorbalık türünün de değiştiği belirtilmektedir. Küçük sınıftaki öğrencilerde fiziksel zorbalığın, büyük sınıftaki öğrencilerde ise sözel ya da psikolojik zorbalığın daha yaygın olduğu ifade edilmektedir (Pişkin, 2002, s.12).

Arkadaş beğenisinin önem kazandığ1 8-12 yaşlar, gruplaşma döneminin başlangıcı olarak görülmektedir. Takıma bağlı olmak ve takımla işbirliği içinde olmak bireysel yarıştan üstün görülebilir. Çocuklar açısından bir gruba ait olmak ve grupla uyum içerisinde olmak son derece önemlidir (Yavuzer, 2016, s.25-26). Çünkü çocuklar başkaları tarafından beğenilmek ve takdir edilmek istemekte ve popüler olmayı önemsemektedir.

$\mathrm{Bu}$ bulguların aksine yaş ve zorbalık ilişkisinin farklı bir şekilde yorumlandığı araştırmalar da vardır. Yaş arttıkça zorbalığın azaldığı ve lise döneminde zorbaca davranışların daha az sergilendiği belirtilmektedir. Bu değişimin sebebi olarak da öğrencilerin delikanlılık dönemine geçişleri gösterilmektedir. Diğer bir faktör de okul kültürüyle birlikte öğrencilerde meydana geldiği belirtilen değer sistemidir. Değer sistemiyle birlikte istenmeyen davranışlar reddedilmekte ve mağduru koruma ve sempati duyma gelişmektedir (İrfaner, 2009, s.30).

Rigby ve Slee (1991, s.625) Avusturya'daki okullarda liseye geçiş sürecinde (ortalama 12 yaş) öğrencilerin kendilerinden daha büyük ve daha olgun öğrencilerin bulunduğu bir ortamda bulduklarını ifade etmektedir. 
$\mathrm{Bu}$ durumun öğrencilerin fiziksel anlamda kendilerinden daha güçlü öğrenciler tarafından daha kolay kurban seçildikleri bir ortamı oluşturduğunu belirtmektedir. Çünkü fiziksel anlamda bir güç dengesizliği söz konusu olmaktadır. Bu araştırma sonuçlarına göre daha küçük olanlar daha sık zorbalığa maruz kalmakta ve bu durum erkekler arasında daha yaygin olmaktadır.

\section{Cinsiyet}

Zorbalık yaygınlığını araştıran çalışmalar cinsiyetin zorbalıktaki etkisi üzerinde farklı sonuçlar elde etmektedir. Bazı araştırmalar erkeklerin daha çok fiziksel zorbalık olaylarına karıştıklarını göstermektedir. Bazı araştırmalar erkeklerin zorbalık olaylarında daha çok kurban seçildiklerini vurgularken bazı araştırmalar da kızların daha çok kurban seçildiklerini belirtmektedir. Ancak bu araştırma bulguları hem kızların hem de erkeklerin okulda zorbalık olaylarına karıştıklarını göstermektedir (Wei ve Williams, 2004, s.560).

Zorbalığın, öğrencilerin cinsiyetiyle ilişkili olabileceği düşünülerek çeşitli ülkelerde bu amaçla farklı araştırmalar yapılmıştır. Literatür incelendiğinde hem zorbalık yapan, hem de zorbalığa uğrayan öğrencilerin önemli bir bölümünün erkekler olduğu görülmektedir (Pişkin, 2002, s.541; Tipırdamaz-Sipahi, 2008, s.9).

Diğer taraftan bazı araştırmalar incelendiğinde erkeklerin zorbaca davranışta bulundukları ve kızların erkeklere göre daha çok zorbalığa maruz kaldıkları görülmektedir. İngiltere'de gerçekleştirilen bir araştırmada zorbalık davranışının \% 65'nin erkekler \% 15'inin kızlar ve \% 19'nun hem kız hem erkekler tarafından gerçekleştirildiği ortaya çıkmıştır (Satan, 2011, s.58).

Birçok araştırmada, erkek ve kız öğrencilerin zorbalığa uğrama biçimlerinin de farklı olduğu ifade edilmektedir. Bazı araştırmalarda erkek öğrencilerin daha çok diğer erkek öğrenciler tarafından dövülme, tekmelenme, itilme ve benzeri fiziksel zorbalığa maruz kaldıkları, kız öğrencilerin ise daha çok her iki cinsin ad takma, dalga geçme, alay etme, dedikodu yapma gibi sözel içerikli zorbalığa uğradıkları ve sosyal olarak dışlandıkları bulunmuştur (Baldry, 2003, s.721; Tıpırdamaz-Sipahi, 2008, s.9; Pişkin, 2002, s.11). 
ABD'de 230 farklı okuldan 6-7-8-9-10. sinıflardan 7,182 öğrenciyle yapılan araştırmada cinsiyete bağlı olarak erkeklerin (zorba-kurban-hem zorba hem kurban) ilişkisel zorbalığa nazaran daha çok fiziksel ve sözel zorbalık olaylarına dahil oldukları ortaya çıkmıştır (Wang vd., 2009, s.371-374).

Rigby (2007, s.45-46) zorbalığın cinsiyet bağlamında benzerlik ve farklılıklarını şu şekilde özetlemiştir:

1. Haftada en az bir kez akranları tarafından zorbalığa maruz kaldığını ifade eden 8-17 yaş arasındaki öğrenci oranı her iki cins için de \% 18 ve üstüdür. Ancak erkeklerde bu oran biraz daha yüksektir.

2. Tüm yaş grupları için kızların fiziksel olarak zorbalığa uğrama olasılı̆̆ 1 daha düşüktür.

3. Ancak dolaylı yollarla zorbalığa maruz kalma ihtimali daha yüksektir. Sözlü zorbalığa maruz kalma açısından her iki cins için de bir benzerlik söz konusudur.

4. Hem erkekler hem de kızlar birey ve gruplar tarafından zorbalığa maruz kalmaktadır, ancak grup zorbalığının kızlarda görülme ihtimali daha yüksek olmaktadır.

5. Hem kızlar hem de erkekler hemcinsleri ve karşı cins tarafından zorbalığa maruz kalmaktadır. Ancak karma eğitim uygulayan okullarda kızların karşı cinsten zorbalığa maruz kalmaları daha yaygın olmaktadir.

6. Hem erkek hem kızlar büyüdükçe; fiziksel zorbalık diğer zorbalık türlerine nazaran azalmakta, sözel zorbalık nispeten yaşla orantılı olarak daha sık görülmekte, diğer zorbalık türleri ise aynı şekilde devam etmektedir.

7. Karma eğitim veren okullar ile tek cinsiyete dayalı eğitim veren okullar arasında kızlar ve erkekler için akran zorbalığı bakımından bir farklılık bulunmamıştır.

8. Tipkı erkeklerin zorbalığa daha çok maruz kalması durumunda olduğu gibi, erkekler benzer şekilde kendilerini daha çok zorba olarak tanımlamaktadır. Hem erkekler hem kızlar büyüdükçe ortaokullarda daha az zorbaca davranmaktadır, ancak bu azalma eğilimi kızlarda daha erken olmaktadır. 
9. Her iki cinsten de öğrenciler okullarını incinebilir, zayıf çocuklar için güvensiz olarak nitelemelerine rağmen, kızlar daha çok okullarını güvensiz olarak niteleme eğilimindedir.

Cinsiyetin akran zorbalığına etkisini inceleyen diğer bazı araştırmaların sonuçları farklılık göstermekle birlikte erkeklerin kız öğrencilere göre zorbalığa daha çok maruz kaldıkları belirtilmektedir (Uludağlı ve Uçonak, 2005, s.78; Pişkin, 2002, s.541; Tipırdamaz-Sipahi, 2008, s.9). Diğer bazı araştırmalara (Dölek, 2002, s.79; Gültekin ve Sayıl, 2005, s.49) bakıldığında ise cinsiyetler arasında zorbalığa maruz kalma bakımından fark olmadığı görülmektedir. Ancak yapılan araştırmaların çoğunda erkeklerin daha fazla zorbaca davranışlara başvurdukları belirtilmiştir (Uludağlı ve Uçonak, 2005, s.78). Bununla birlikte saldırganlık bakımından erkeklerin daha çok fiziksel kızların ise ilişkisel saldırganlığa maruz kaldıkları ifade edilmektedir (Dake vd., 2003, s.2; Uludağlı ve Uçonak, 2005, s.78; Tipırdamaz-Sipahi, 2008, s.9; Satan, 2006, s.24).

Zorbalıktaki cinsiyet farklılığının araştırıldığı Boulton ve Underwood (1992)'un çalışmasında erkeklerin kızlara nazaran daha çok zorbalık eğilimli oldukları bulunmuştur. Bu araştırmalarda mağdurlar zorbalığın \%65'nin erkekler tarafından \%15 'inin kızlar tarafından \% 19' unun ise hem erkekler hem de kızlar tarafından yapıldığını ifade etmiştir. Rigby (1995) de benzer sonuçlar elde etmiştir. Araştırmada 4. sınıftan 8. sınıfa kadar olan öğrencilerden zorbalığa başvuran erkeklerin oranı \% 23 iken kızların oranı \% 8'de kalmıştır (Akt. Satan, 2006, s.25). Bu araştırmaların bulgularından hareketle oranlar değişmekle beraber erkek öğrencilerin kız öğrencilere göre zorbalığa daha çok başvurduğunu söylemek mümkündür. Yine Alikaşifoğlu'nun belirttiğine göre öğrenci bildirimlerine dayanan araştırmalar neticesinde erkek öğrencilerin kız öğrencilere oranla daha çok zorbalık yaptıkları anlaşılmaktadır. (Alikaşifoğlu ve Ercan, 2007, s.21)

Zorbalığa başvuran öğrencilerin kurban olarak seçtikleri kişilerin kendi cinslerinden mi yoksa karşı cinsten mi olduğu da cinsiyetin zorbalık davranışı üzerindeki etkisini belirlemesi açısından önemlidir. Hayden ve Thomson (1987; akt. Satan, 2006, s.25) ve Maccoby (1988; akt. Satan, 2006, s.25) çalışmaları ilkokuldan ortaokul dönemine kadar öğrencilerin zorbalığa başvurmada hemcinslerini tercih ettiklerini göstermektedir. 192 çocuk ile yapılan çalışmada zorbaların aslında her iki cinse de zorbaca 
davrandığı ancak daha çok kendi hemcinslerini hedef olarak seçtikleri belirtilmektedir. Ahmad ve Smith (1994; akt. Satan, 2006, s.25) tarafından yapılan araştırmalar da aynı görüşü desteklemektedir.

Yapılan bazı araştırmalar erkeklerin zorbalık davranışlarına daha çok maruz kaldıklarını ancak zorbalık davranışı sonrasında kızların daha fazla üzüntü duyduklarını göstermektedir. Bu anlamda kızların erkeklere nazaran duygusal anlamda daha çok etkilendiklerini ve gelişimlerini olumsuz etkilediğini söylemek mümkündür. Yine bu araştırmalarda kızların maruz kaldıkları zorbalığı aile ve yakın arkadaşlarıyla paylaşmayı tercih ederken, erkeklerin genel olarak kimseyle paylaşmamayı tercih ettiği vurgulanmıştır ( Pişkin, 2002, s.11).

\section{Fiziksel Özellikler}

Kurbanların fiziksel anlamda daha güçsüz ve küçük oldukları belirtilmektedir. Bu özellikleri sebebiyle zorbalara karşı kendilerini korumakta yetersiz kalmaktadırlar (Albayrak, 2012, s.22). Kurbanların spora ilgisi azdır ve sporda başarısızdırlar. Acı eşikleri düşüktür ve korkaktır (Dölek, 2002, s.41; Albayrak, 2012, s.21). Olweus (2003) fiziksel yetersizliklerin (görme, duyma gibi) ve şişmanlık, temizlik ve giyim gibi fiziksel özelliklerin kurban olmak ile bağını çok desteklememektedir. Bununla birlikte ona göre fiziksel anlamda en önemli özellik vücut ölçüleridir (Tipırdamaz-Sipahi, 2008, s.12). Unicef (2015)' in Jamaica raporuna göre öğretmenler fiziksel görüntü bakımından daha az erkeksi, zayıf, daha küçük, bakımsız, dağınık ve yoksul görünen çocukların mağdur olduklarını belirtmektedir (Unicef Jamaica Report, 2015, s.29).

West ve Salmon (2000; akt. Gökler, 2007, s.52) kurbanların fiziksel anlamda hasta gibi hissettiklerini ifade etmektedir. Bu nedenle mide bulantısı, baş dönmesi, kol-bacak ağrıları gibi nedenlerle doktora başvurduklarını belirtmektedir. Bu tür teşhisi bulunmayan rahatsızlıklar konusunda doktorların zorbalığa dikkat çekmelerini istemektedir. Ayrıca bu rahatsızlıkların psikolojik sorunları da ortaya çıkardığına işaret etmektedir. 


\section{Kişilik Özellikleri}

Cüceloğlu (2015, s.404)'na göre kişilik “bireyin iç ve diş çevresiyle kurduğu, diğer bireylerden ayırt edici, tutarlı ve yapılaşmış bir ilişki biçimi" anlamındadır. Yapılan araştırmalarda genel olarak zorbaca davranan bireylerin kişilik özellikleri benzerlik göstermektedir. Saldırganlık davranışında bulunmaları en dikkat çekici özellikleridir. İstediklerini elde etmek için çoğu zaman şiddete başvururlar. Ayrıca bu davranışı sadece akranlarına değil ebeveyn ve öğretmenlerine de sergilemektedirler (Külcü, 2015, s.17-18).

Düşük benlik saygısı, akranlarının başarılarını kıskanma gibi özellikler de davranışlarının önemli bir kısmını oluşturmaktadır (Külcü, 2015, s.1718). Ancak bazı araştırmalarda farklı sonuçlar da elde edilmiştir. Örneğin Pişkin ve Ayas (2005; akt. Gökler, 2009, s.515)'ın liseli öğrencilerle yaptıkları araştırma sonuçlarına göre zorbaların benlik saygılarının yüksek olduğu bulunmuştur.

Zorba ve mağdurların çeşitli yönlerden karşılaştırıldığı araştırmalarda zorbaların mağdurlara nazaran benlik saygılarının daha düşük olduğu vurgulanmaktadır. Buna karşın bazı araştırmalar ise zorbalık yapma ile özsaygı arasında bir ilişki olmadığını belirtmektedir. Yine zorbaların anksiyete düzeylerinin daha düşük olduğu ve depresyon yaşamaya eğilimli oldukları ifade edilmektedir. Şiddet eğilimi ve şiddete yönelik eğilim üzerine yapılan araştırmalarda ise zorbalık yapan öğrencilerin zorbalığa hiç bulaşmamış öğrencilere nazaran şiddeti daha destekleyici ve olumlu karşılama tutumu sergiledikleri bulunmuştur. Zorbaca davranışların doğru olup olmadığı üzerine yapılan araştırmalarda ise hem zorbaların hem de mağdurların bireyin zorbaca davramılmayı hak ettiğine dair bir inanca sahip oldukları vurgulanmaktadır. Zorbaların bu şekilde düşünmeleri anlaşılabilir bir durumken mağdurların neden bu şekilde düşündüklerini anlamak zordur. Ancak bu durumun nedeninin "öz suçlama " olabileceği düşünülmektedir (Yaman vd., 2011, s.73-77).

Kurbanların özelliklerine bakıldığında ise fiziksel olarak zayıf, kendini koruyamayan, zorba davranışlar karşısında kaçma, ağlama gibi tepkiler gösteren, duyarlı, sakin ve özsaygıları düşük kişiler oldukları görülmektedir (Külcü, 2015, s.17-18). 


\section{Aile Özellikleri}

Zorbalığı ortaya çıkaran faktörler arasında aile önemli bir yere sahiptir. Sağlıksız aile olarak nitelendirilen ailelerin çocukları daha çok problemlerle karşılaşmaktadır. Sevgi, ilgi ve bakımın yanında aile üyeleri arasındaki etkileşim ve iletişim de çocuğun gelişimini ve davranışlarını önemli ölçüde etkilemektedir. Olweus (1993; akt. Gökler, 2007, s.52) zorbalıkla daha çok karşılaşılan okullarda çocukların ailelerinin "doyurucu olmayan çocuk yetiştirme tarzına" sahip olduklarını ifade etmektedir. Problemli ailelerde görülen boşanma, çatışmalı ilişkiler, alkol ve madde bağımlılığı gibi sorunların zorbalığın görülme sıklığını arttırdığını belirtmektedir.

Öz saygı geliştirmede en önemli faktörlerden biri çocuğun ebeveynleri ile ilişkisinin doğasıdır. Çocuklardan hoşlanan ve ihtiyaçlarına karşı sorumlu davranan ve duygusal destek sağlayan ebeveynlerin çocukları öz saygı gelişimleri daha sağlıklı olmaktadır (Yalom, 2007, s.38-39). Çocuk benlik saygısı aile üyeleri arasındaki ilişkilerden etkilenebilmektedir. Özellikle anne-çocuk arasındaki ilişki belirleyici olabilmektedir (Yavuzer, 2013; akt. Gökgöz, 2014, s.32). Çocuğun ihtiyaçlarını karşılayan annenin uygun davranışlarla bunu yerine getirmesi çocukta değerli olma ve çevresine güvenme hissi verir (Altınköprü, 2004; akt. Gökgöz, 2014, s.32).

Diğer taraftan çocukların yargılanması, suçlanması onların benlik saygısını olumsuz etkileyebilir, ebeveynlerle iletişimini zedeleyebilir ve çocukta değersizlik ve aşağılanmış olma hislerini uyandırabilir. Bu özsaygı yetersizliği anne-baba ve çocuk arasındaki ilişkiye de yansıyarak çocuğun ebeveynlerine karşılık vermesine neden olabilir (Çağdaş, 2012; akt. Gökgöz, 2014, s.32).

Öz saygı, okul çağı döneminde akademik ve sosyal görevlerdeki başarıyla beraber gelişir. Çocuklar ebeveynlerinin, öğretmenlerinin ve akranlarının değerlendirmelerine göre kendi hakkındaki düşünceleri gelişir. Kabul gören çocuklar kendileri hakkında iyi duygular beslerken, sürekli eleştirilen ve reddedilen çocuklar kendilerini yetersiz olarak görürler (Yalom, 2007, s.38-39).

İtici tutumlara sahip ebeveynlerin çocukları kendini değersiz bulabilmektedir. $\mathrm{Bu}$ tür ortamlarda yetişen çocukların kendi hakkında görüşleri olumsuz olabilmektedir. İstenilen davranışı yaptığ 1 halde annebabanın onayını alamayan çocuk artık bundan vazgeçer, umudunu yitirir. 
Reddedilen çocukların maruz kaldığı hırçın davranma, azar, dayak ya da gereksiz yere ceza verme, ilgisizlik, çocuğu terk etme ya da kötü sıfatlarla çağırma gibi davranışlar çocuğa yöneltilen itici-reddedici davranışlardır. Bu tür davranışlar çocuğun giderek kendini daha da değersiz görmesine neden olur (Gençtan, 2016, s.46-47).

Çocukluk dönemindeki yaşantılar diğer dönemlere de yansımaktadır. İnsanlarla birlikteyken yaşanan genel bir korku, önyargının sebep olduğu düşmanca eğilimler, suçluluk ve değersizlik duyguları ve günlük yaşamda sorun teşkil eden kaygılar bu yansımalar arasında gösterilebilir (Gençtan, 2016, s.46-47). Rebirther uzmanı Sondra Ray ilişkiler üzerine birçok araştırma yapmış ve tüm önemli ilişkilerimizin, ebeveynlerimizden biriyle olan ilişkilerimizin yansıması olduğunu savunmuştur (Kurt, 2015, s.157).

Ergenlik döneminde ergenin arkadaşlarıyla geçirdiği zaman çocukluk dönemine nazaran daha fazla olmaktadır. Ergen akranlarından etkilenmektedir ancak anne-babanın önemi bazı konularda genç için hala devam etmektedir. Özellikle okul, meslek seçimi ve gelecekle ilgili konularda ergen için anne-babanın fikirleri önemini korumaktadır (Kulaksızoğlu, 2017, s.86). Çünkü ebeveynler doğumdan itibaren çocukların dünyayı tanımalarına ve anlamlandırmalarına yardım etmektedir. Bunun yanı sıra ebeveynler hem kendi davranışlarıyla hem de bilgi yoluyla çocuklara aktarımda bulunarak sosyalleşmelerini sağlamaktadır. Ayrıca kültürel değerlerin aktarılmasında ve inançların öğretilmesinde büyük rol oynamaktadırlar (Yalom ve Steiner, 2007, s.34).

Çocuk dünyaya geldiği ilk andan itibaren anne-baba ve diğer üyeler ile etkileşim içerisindedir. Dolayısıyla kişilik yapısının oluşmasında aile faktörü önem arz etmektedir (Yörükoğlu, 1989; akt. Çapulcuoğlu ve Gündüz, 2013, s.204). Uyumlu, tutarlı ve sağlıklı aile yapısına sahip çocuklar daha özerk bir gelişimle yaşamını sürdürür (Yavuzer, 2009; akt. Çapulcuoğlu ve Gündüz, 2013, s.204). Anne babanın çocuğun davranışlarına ve isteklerine yaklaşımları benlik oluşumunu da etkilemektedir. Bununla birlikte anne-baba tutumlarının okul başarısı, kaygı, bağımsızlık ve problem çözme becerileriyle yakından ilgili olduğu bazı araştırmalarca tespit edilmiştir (Düzgün, 1995, s.35-45).

Anne-babanın çocuğa yönelik tutumu üzerine yapılan çalışmalar ebeveynin ve daha çok da annenin fiziksel, psikolojik ve sosyal yönden 
çocuğun gelişimi üzerinde etkili olduğunu vurgulanmaktadır. Annenin çocuk üzerinde daha etkili olmasının sebebi ise annenin babaya nazaran çocukla daha fazla zaman geçirmesi olarak belirtilmektedir (Kulaksızoğlu, 2017, s.118).

Ailenin işlevini sağlıklı bir şekilde yerine getirmesi çocuğun daha sağlıklı gelişim göstermesi ve uygun davranışlar sergilemesiyle yakından ilgilidir. Buna karşın sorunlu ailelerde yetişen çocukların da daha sapkın ve uygunsuz davranışlar sergilediği görülmektedir. Ayan (2007, s.207)'nın yaptığı araştırma sonuçları da bu görüşü destekler niteliktedir. 2006 yılında Sivas merkezde 655 ilkokul öğrencisiyle yapılan görüşmelerde öğrencilerin \% 43,4'ü aile içi şiddete maruz kaldığı ortaya çımıştır. Şiddete uğrayan öğrencilerin saldırganlık ölçeği puanı daha yüksek çıkmıştır. Diğer bir ifadeyle analiz sonuçlarına göre şiddete uğrayan öğrencilerin daha çok saldırganlık eğilimi gösterdiği anlaşılmaktadır.

Alan yazında çocuk yetiştirme tarzının çocuğun yaşamında büyük rol oynadığı üzerinde önemle durulmaktadır. Çünkü ebeveynler doğumdan itibaren çocuklarına dünyayı tercüme eder, ruhsal ve duygusal yönden gelişimlerine katkıda bulunurlar. Bununla birlikte dini ve kültürel unsurların çocuğun yaşamında yer edinmesine yardım ederler. Çocuklar büyüdükçe ebeveynler onların hayatında daha da etkili olmak ister ve direktiflerine daha fazla uyulmasını beklerler. Ancak ebeveynlerin annebabalık tarzlarında önemli farklılıklar vardır (Yalom ve Steiner, 2007, s.3839). Bu bakımdan anne baba tutumlarına değinmekte yarar vardır.

Kişiliğin oluşumunda ebeveyn tutumları farklılık göstermekle birlikte anne-babanın çocuğa yaklaşımı önemli bir yere sahiptir. Anne-baba tutumlarına yönelik birçok sinıflandırma yapılmakta ancak burada demokratik, otoriter ve aşırı hoşgörülü anne baba tutumlarına değinilmiştir.

Demokratik anne-baba tutumu: Bu tutuma sahip anne babalar daha akılc1 bir biçiminde çocukları yönlendirme, onları ayrı bir birey olarak değerlendirerek bağımsız bir kişilik geliştirmelerine yardımcı olma eğiliminde olan ebeveynlerdir (Kulaksızoğlu, 2017, s.118). Çocukların gelişimi için en doğru tutum olarak belirtilmekte ve ebeveynlerin koşulsuz bir şekilde sevgi gösterdikleri belirtilmektedir. Bu tutumu sergileyen ebeveynlerin çocukların ihtiyaçlarını önemsediklerini, tutarlı ve güven verici davranışlar sergiledikleri vurgulanmaktadır (Sezer, 2010, s.3). 
Otoriter anne-baba tutumu: $\mathrm{Bu}$ ebeveyn tutumunda çocuğun davranışlarını kontrol etmeye ve şekillendirmeye yönelik bir eğilim vardır. Anne-baba çocuğun kendisine itaat etmesini ve kendi sözlerinin doğru olarak kabul edilmesini beklemektedir. Çocukların duygu ve düşünceleri önemsenmez ve bunların bastırılmasına neden olunmaktadır. Bedensel cezalandırma çocuğun istenmeyen davranışlarına karşı kullanılmaktadır (Kulaksızoğlu, 2017, s.122). Bu ebeveynler, otoriteye saygiya, geleneğe ve mevcut düzenin korunmasına özen gösterirler. Bireyselliğe ve bağımsızlığa önem vermezler (Yalom ve Steiner, 2007, s.34). Bastırılan ve önemsenmeyen duygular erkek çocukları saldırganlığa ve düşmanca davranmaya yöneltebilir (Kulaksızoğlu, 2017, s.122; Yalom ve Steiner, 2007, s.34). Kızlar ise bağımlı, hırssız ve düşük okul başarısı sergileyebilmektedirler (Yalom ve Steiner, 2007, s.34).

Aşırı hoşgörülü anne-baba tutumu: Toleranslı anne baba tutumu olarak da ifade edilmektedir. Çocuğun cinsellik ve saldırganlık dürtüleri de dahil olmak üzere genel anlamda çocuğun talepleri onaylanmaktadır. Otoriteyi çocuk üzerinde uygulamayan ve cezalandırmadan kaçınan bir tutum söz konusudur (Yalom ve Steiner, 2007, s.34).

Özetle anne-baba tutumları değerlendirildiğinde, aşırı hoşgörülü ve disiplin eksikliği çocuğun bencil ve toplumla zıt davranışlar sergilemesine neden olur. Katı disiplin, anne-babaya karşı öfke ve korku yaşanması, girişim eksikliği ve insanlara dostça yaklaşamama gibi istenmeyen sonuçlar doğurur. Aşırı kısıtlayıcı tutumlar ise, başkaldırıcı davranışlarla sonuçlanır. Anne babanın görüşlerine aykırı dış etkenlere bir yönelme olmaktadır (Gençtan, 2016, s.48).

Zorba ve kurbanların ailelerinin araştırıldığı birçok araştırmada zorba çocukların aileleri genelde sert ve güç kullanma yanlısıyken, kurban çocukların aileleri genellikle çocuğu koruma eğiliminde olmaktadır. Çünkü aile içerisinde gösterilen saldırgan davranışlar çocuk için model oluşturabilmektedir. Bu konuda yapılan bazı araştırmalarda tutarsızlık, yetersiz ilgi ve sevgi, aile içi sert ilişkiler ve saldırganlık ile yetersiz denetim gibi davranış ve ilişkilerin çocuğun saldırgan davranışlar sergilemesinde tetikleyici rol oynayabileceği vurgulanmıştır (Sarıtaş, 2006, s.18). 
Ayan da çocuğun aile içinde şiddete maruz kalmasında birçok faktöre dikkati çekmektedir. Ailenin psiko-sosyo-ekonomik durumu, ebeveynlerin sosyokültürel durumları, evliliğe ilişkin sorunlar ve anne-babanın çocuğa yönelik tutumları aile içi şiddet olgusunu belirlemektedir. Aile içi sorunlar ve şiddet çocuğun günlük yaşamında hem zorba olmasını hem de kurban olmasını etkilemektedir. Çünkü şiddetle yüzleşen çocuk hırçın, öfkeli, huysuz ve sinirli olabilmektedir. Bu davranışlar birçok sonucu ortaya çıkarmakla beraber en önemli sonucun "şiddet gören şiddet uygular" ihtimalidir (Ayan, 2007, s. 207). Külcü aile içerisinde ceza olarak şiddeti kullanan ve çocukla ilişkilerinde tutarsız davranan ebeveynlerin çocuklarının zorbalığa daha eğilimli olduğunu belirtmektedir (Külcü, 2015, s.17-18). Sarıtaş da 225 ilköğretim 7 ve 8. sınıf öğrencileriyle yaptı̆̆ çalışmada benzer bulgulara ulaşmıştır (Sarıtaş, 2006, s.5; Türktan, 2013, s.59).

Ailenin çocuğun zorba davranışı üzerindeki etkisini inceleyen Yurttaş'ın 2010 yılında yaptığı araştırmaya yaşları 11-15 arasında olan 467 öğrenci katılmıştır. Araştırma sonuçlarına göre ebeveynleri demokratik davranan öğrencilerin ebeveynleri baskıcı-otoriter davranan öğrencilere göre fiziksel zorbalık eğilimleri daha düşük çıkmıştır (Türktan, 2013, s.60; Yurttaş, 2010, s.159). Yine Akgün'ün ebeveyn tutumları ve ergen ilişkileri ile bu ilişkilerin zorbalığa etkisini inceleyen araştırmasına yaşları 13 ile 18 arasında olan 379 ergen katılmıştır. Araştırmada psikolojik özerklik ve denetleme bakımından olumsuz ebeveynlerle negatif iletişimin olduğu çocukların daha çok mağdur olduğu belirtilmiştir (Akgün, 2005, s.50; Türktan, 2013, s.58).

\section{Sosyo-Ekonomik Durum}

Yurttaş'ın yaptığı araştırma sonuçlarına göre ekonomik anlamda üst ve orta düzeydeki öğrencilerin alt gelir düzeydeki öğrencilere göre zorbalık eğilimlerinin daha yüksek olduğu bulunmuştur (Türktan, 2013, s.62; Yurttaş, 2010, s.40-50). Bu anlamda sosyo-ekonomik durumun çocuğun zorbalık davranışında bulunmasını etkilediğini söylemek mümkündür.

UNICEF'in Jamaica Raporunda öğretmenler, zorba öğrencilerin düşük sosyo-ekonomik yaşamdan gelen, gettoda yaşayan, kaynak yetersizliği olan ve yetersiz okul malzemesine sahip, kurban öğrencilerin ise paralı, 
yüksek sosyo-ekonomik geçmiş ve zengin çocuklar olduğunu bildirmiştir (Unicef Jamaica Raporu, 2015, s.28-29).

Zorba davranışına başvuran çocukların gruplara katılma ya da grup tarafından kabullenme durumları üzerine çeşitli araştırmalar yapılmıştır. Akranları ile ilişkilerinde kabul görme ya da reddedilme gibi farklı tepkilerin söz konusu olduğu görülmektedir. Bazı araştırmalar (Austin ve Joseph, 1996; Perry vd., 1988; akt. Uludağlı ve Uçonak: 2005, s.80) zorbaların daha çok reddedildiklerini belirtirken bazı araştırmalar (Cairns vd., 1988; akt. Uludağlı ve Uçonak, 2005, s.80) saldırgan çocukların diğer saldırgan çocuklar tarafından daha kolay kabul gördüklerini ve bu tür gruplarda popüler olduklarını belirtmektedir.

\section{Psikolojik Özellikler}

Kurban ve zorbaların psikolojik özelliklerinin incelendiği araştırmalarda zorbalığa maruz kalan öğrencilerin çeşitli zihinsel sağlık risklerini taşıdıkları bulunmuştur. En yaygın psikolojik problemin depresyon olduğu görülmüştür. Zorbalığa hiç karışmayan öğrencilerle karşılaştırıldığında zorbaların 2.8 ile 4.3 ; kurbanların 4.0 ve zorba-kurbanların 6.3 ile 8.8 oranında depresyon yaşama durumları olduğu görülmüştür (Dake vd., 2003, s.2).

\section{Davranışsal Özellikler}

Unicef'in Jamaica Raporunda öğretmenler zorbalık sürecine ilişkin görüşleri alınmıştır. Raporda öğretmenler zorbalığa maruz kalan öğrencilerin farklı davranan, sessiz ve yumuşak konuşan, farklı görünebilen, misilleme yapmayan, şikayet etmeyenler, sessiz olanlar, kendilerini savunamayan, karşılık vermeyen, çok çı̆̆lık atan, iyi huylu ve konuşkan, uysal, dakik, yaramaz, az konuşan, ürkek, çekingen öğrenciler olduklarını ifade etmektedir (Unıcef Jamaica Raporu, 2015, s.28).

\section{Etnik ve Irksal Özellikler}

Zorbalığa maruz kalma ya da zorbaca davranma yaygınlığı açısından 1rksal ve etnik gruplar incelendiğinde Birleşik Krallıktaki çalışmalar bu 
gruplar arasında önemli bir fark olmadığını bulmuştur. Ancak İngiltere ve Almanya' dan öğrenci içeren uluslararası bir çalışma zayıf ancak önemli bir ilişki bulmuştur. Etnik grup ve zorbalık arasındaki bu ilişkinin etnik azınlığın mağdur olmayı beraberinde getirdiği yönündedir. ABD'de ise üç araştırma bu konuyu incelemiştir. En büyük araştırmada Afro Amerikan, Latin Amerikan ve beyaz çocuk açısından zorbalık ya da kurban olma bakımından önemli bir fark bulunmamıştır. Diğer araştırmada AfroAmerika ve beyaz çocuklar arasında Afro-Amerikalı çocukların daha çok azalan bir oranda mağdur olduğu bulunmuştur. Kaliforniya'daki araştırmada ise azınlığı beyaz öğrenciler çoğunluğu ise Afro-Amerikan ve Latin Amerikan çocuklar oluşturuyor. $\mathrm{Bu}$ araştırma sonucunda beyaz çocukların Afro-Amerikan ya da Latin Amerikan çocuklarına göre mağdur olma bakımından daha yüksek bir ihtimal olduğu bulunmuştur. Afro-Amerikan öğrencilerin akranları arasında daha saldırgan oldukları ortaya çıkmıştır (Dake vd., 2003, s.2).

$\mathrm{ABD}^{\prime}$ de 6-7-8-9-10. sinıflardan Afro-Amerikan, İspanyol ve Kafkas ırklarından 7.182 öğrenciyle bir araştırma yapılmıştır. Kafkaslarla kıyaslandığında Afro-Amerikan ırkından olanların daha çok (fiziksel, sözel, siber) zorba davranışlarında bulundukları ve daha az (ilişkisel, sözel) mağdur oldukları ortaya çıkmıştır. İspanyol ergenlerin Kafkas ergenlere nazaran daha çok fiziksel zorba ya da siber zorba-kurban olma eğiliminde oldukları belirtilmiştir (Wang vd., 2009, s.372).

\section{Sonuç}

Ergenlik çağındaki gençlerle yapılan araştırmalar bu döneme ilişkin bazı ortak sorunlara değinmektedir. Ancak yine de bu dönemde yaş grubu, okula devam edip etmeme, ebeveyn tutumları, ergenin çevresi tarafından kabul edilip edilmeme sorunsalı gibi faktörler sorunların çeşitlilik göstermesinde etkin rol oynamaktadır (Kulaksızoğlu, 2016, s.76).

Zorbaca davranışların altında ve kurbanların seçilmesinde kişilik özellikleri, cinsiyet, aile içi iletişim gibi faktörler önemli bir etkiye sahiptir. Genel olarak demokratik tutuma sahip ve çocuğa ilgi ve sevginin gösterildiği ebeveynlerin çocukları zorbalık olaylarına daha az karışmaktadır. Aile ve sosyal çevre içerisinde değer gören çocuklar diğerlerine göre 
okulda daha başarılı olmakta, okula daha düzenli devam etmekte ve şiddet olaylarına daha az karışmaktadırlar. Bununla birlikte sinirli bir yapıya sahip olma, gereksinimlerini karşılamak için bazı kişiler üzerinde güç ve baskı kurma ve popüler olma isteği gibi özellikler bireyleri zorbaca davranışlara itebilmektedir. Diğer taraftan baskıcı ve otoriter tutuma sahip ebeveynlere sahip olmak, aile içi şiddete maruz kalmak veya tanıklık etmek, akranlarından fiziksel olarak herhangi bir farklılığa sahip olmak (kilo, boy gibi), kendini savunmada yetersiz kalmak ve daha az arkadaşa sahip olmak gibi özellikler de kurbanların seçilmesinde belirleyici olmaktadır.

Literatür incelendiğinde zorbaca davranışları yordayan yaş, cinsiyet, ebeveyn tutumu, bireyin özellikleri gibi birçok karmaşık etkenin olduğu belirtilmektedir. Zorbalığın sonuçları düşünüldügünde zorbalık olaylarından sadece mağdurların değil zorbaların ve seyirci kalanların da etkilendiği anlaşılmaktadır. Örneğin mağdurlarda stres, depresyon, özgüven eksikliği ve akademik başarının düşmesi gibi etkileri görülürken; zorbalarda ileride suç olaylarına karışma oranı daha yüksek olma ve akademik sorunlar; seyircilerde ise kaygı, çaresizlik ve suçluluk hissine kapılma gibi olumsuz sonuçlar doğurduğu görülmektedir. Bu bakımdan zorbalık ne türde uygulanırsa uygulansın, nerede görülürse görülsün zorbalık olaylarına karışan tüm bireyleri risk altında bırakmaktadır.

Zorbalığın sonuçlarını değerlendirmek gerekirse düşük psikolojik iyilik hali, sosyal uyum problemleri, baş ağrısı ve uykusuzluk gibi fiziksel rahatsızlıklar, düşük benlik saygısı, alkol-tütün gibi madde kullanımı, öğrenme kapasitesinde düşme, okuldan ayrılma veya okula devam sorunu, suçluluk duyguları ve suça karışma gibi birçok olumsuz sonuçtan bahsedilebilir.

Dan Olweus birçok zorbalık önleme programı geliştirmiş ve bu alanda çok kapsamlı araştırmalar yapmıştır. Pişkin (2005; akt. Gökler, 2009, s.515)'nin ülkemiz için ifade ettiği \% 11 ile \% 50 arasındaki zorbalık davranışlarının görülme sıklığı Türkiye açısından da benzer şekilde şiddet önleme programlarının gerekliliğini destekleyici nitelik taşımaktadır. Ancak bu şekildeki programların geliştirilebilmesi için konunun detaylıca ele alınması, neden ve sonuçlarının irdelenmesi zorbalık olaylarına karışan tüm bireylerin tanımlanması gerekmektedir. Bu sayede hem okulda hem okul dışında görülen akran zorbalığına daha kalıcı çözümler getirilebilir. 
Çünkü birey, bireyin ailesi ve çevresi katkı sunmadan ve zorbalığın gerçekleştiği ortamlarda bazı değişimler gerçekleştirilmeden müdahaleye yönelik atılan adımların etkili olması mümkün görünmemektedir.

Özetle zorbalığın hem nedenleri hem de sonuçları birlikte değerlendirildiğinde aslında birçok etkenin bu olgunun içinde yer aldığı, zorbalık olaylarının görülmesinde zorbalığa karışan çocuklarla birlikte sosyal çevre, aile ve okul ikliminin önemli ölçüde belirleyici olduğu ve zorbalık olaylarının bireyin psiko-sosyal yaşamını etkilediği söylenebilir. Bu noktadan hareketle zorbalığın önlenmesinde birey, aile, okul ve sosyal çevrenin sorunun çözümüne dahil edilmesi gerekmektedir. Bu yönde yeni eğitim politikalarının geliştirilmesi, ailelerin bilinçlendirilmesi, ders programlarına şiddeti önleme ile ilgili derslerin eklenmesi önem arz etmektedir. Bununla birlikte okullarda "okul sosyal hizmeti" birimlerinin kurulması sağlanmalıdır. 


\title{
EXTENDED ABSTRACT
}

\section{Evaluation of Some Factors Predicting Peer Bullying in Adolescents}

\author{
Nurullah Yelboğa - Orhan Koçak \\ Çoruh University, İstanbul University
}

The incidence of bullying among children is based on very old histories. Many individuals have experienced these events in person or have witnessed aggressive behavior towards other children. Today in the world and threatening the lives of children in Turkey, war, migration, drug use, there are many issues such as violence and bullying. The rapid development and change in the cognitive, social and emotional aspects of adolescence can deepen the effects of these problems.

Peer bullying, psychological, such as stress, depression, low self-confidence, negatively affect children's educational life, achievement and commitment to school; it is a problem that has some social consequences such as crime and loneliness. This problem, which is more clearly noticed, especially in cases of absenteeism and decline in academic achievement, makes families, administrators, teachers and children involved in bullying uneasy. The aim of this study is to take preventive and protective measures and to include the individual, social and environmental characteristics in the process for effective solution of the present problem and to make a deeper reading of the problem. For this purpose, first, ran peer bullying lanmıs was defined, the reasons of bullying were discussed, the results of bullying were discussed and then some factors such as age, gender, personality traits and family traits associated with bullying were tried to be explained within the framework of peer bullying.

Different problems are pointed out in determining the situations that cause bullying. Factors such as personality traits, gender, and family communication have a significant effect on bullying behavior and selection of victims. In general, children of parents who have a democratic attitude and affection and love for children are less involved in bullying. . Children who are valued within the family and social environment are more successful at school, attend school more regularly and are less involved in 
violence. However, features such as having a frustrated structure, putting pressure and pressure on some people to meet their needs, and wanting to become popular can push individuals into bullying behavior. On the other hand, having oppressive and authoritarian attitudes, being exposed to or witnessing domestic violence, having any physical differences from their peers (such as weight, height), inadequate self-defense and having fewer friends are among the victims' choices. decisive.

When the consequences of bullying are considered, it is understood that bullying is not only affected by the victims but also the bullies and the audience. For example, the effects of stress, depression, lack of self-confidence and decrease in academic achievement are seen in victims; higher rates of involvement in future criminal incidents in the tyrants and academic problems; and the audience has negative consequences such as anxiety, helplessness and feeling guilty. In this respect, whatever the type of bullying is applied, no matter where it is seen, it puts all individuals involved in the incidents of bullying at risk. Research on the long-term effects of bullying is also common. There is a tendency to exhibit behaviors such as alcohol-tobacco use and fighting. It is emphasized that there is an important relationship between cheating, stealing, taking destructive actions, having problems with police and hanging school and being bullied.

When the literature is examined, it is stated that there are many complex factors such as age, gender, parental attitude, and characteristics of the individual predicting bullying behaviors. When the consequences of bullying are considered, it is understood that bullying is not only affected by the victims but also the bullies and the audience. For example, the effects of stress, depression, lack of self-confidence and decrease in academic achievement are seen in victims; higher rates of involvement in future criminal incidents in the tyrants and academic problems; and the audience has negative consequences such as anxiety, helplessness and feeling guilty. In this respect, whatever the type of bullying is applied, no matter where it is seen, it puts all individuals involved in the incidents of bullying at risk.

In summary, when both the causes and the results of bullying are evaluated together, it can be said that many factors are involved in this phenomenon, the social environment, family and school climate together with the children involved in bullying incidents affect the individual's psycho- 
social life. From this point of view, individuals, families, schools and social environment should be included in the solution of the problem in preventing bullying. In this direction, it is important to develop new education policies, to raise awareness of families and to add lessons about violence prevention to the curriculum. However, 'school social service hizmeti units should be established in schools.

\section{Kaynakça / References}

Akgün, S. (2005). Akran zorbalı̆̆ının anne-baba tutumları ve anne-baba ergen ilişkisi açısından değerlendirilmesi. Yayınlanmamış Yüksek Lisans Tezi, Hacettepe Üniversitesi, Ankara.

Albayrak, S. (2012). Okulda uygulanan zorbalığı önleme programının zorbalı̆̆ın azaltılmasında etkisi. Yayınlanmamış Doktora Tezi, Marmara Üniversitesi, İstanbul.

Alikaşifoğlu, M. ve Ercan, O. (2007). Çocukluk çağında kabadayılık/zorbalık davranışları: Hekimler açısından anlamı. Türk Ped. Araş, 42 (Özel Say1), 19-25.

Anderson, G. (2007). The impact of bullying in school on the adolescent's sense of self. Magister Social Diligentia Play Therapy. Master Thesis, University of Pretoria, Pretoria.

Ayan, S. (2007). Aile içinde şiddete uğrayan çocukların saldırganlık eğilimleri. Anadolu Psikiyatri Dergisi, 8, 206-214.

Baldry, C. A. (2003). Bullying in schools and exposure to domestic violence. Child Abuse \& Neglect, 27, 713-732.

Başaran, A. G. (2014). Rize İli lise öğrencilerinde akran zorbalığı ve zorbalığı önleme eğitimi etkisinin değerlendirilmesi. Yayınlanmamış Doktora Tezi, Cumhuriyet Üniversitesi, Sağlık Bilimleri Enstitüsü, Sivas.

Cüceloğlu, D. (2015). İnsan ve davranışı. İstanbul: Remzi Kitabevi.

Craig, W., Peters, R., ve Konarski, R. (1998). Bullying and victimization among Canadian school children. Applied Research Branch Strategic Policy, Human Resources Development. Canada. 20.12.2017 tarihinde http://citeseerx.ist.psu.edu/viewdoc/download?doi=10.1.1.489.6922\&rep=rep1\&type=pdf, adresinden erişilmiştir.

Çapulcuoğlu, U. ve Gündüz, B. (2013). Öğrenci tükenmişliğini yordamada stresle başaçıkma, sınav kaygısı, akademik yetkinlik ve anne-baba tutumları. Ĕ̆itim Bilimleri Araştırma Dergisi. 3(1), 201-218. 
Dake, J. A., Price, J. H. ve Telljohann, K. S. (2003). The nature and extent of bullying at school. Journal of Scholl Health, 73(5), 173-180.

Demirbaş, M. ve Yağbasan, R. (2005). Sosyal öğrenme teorisine dayalı öğretim etkinliklerinin, öğrencilerin bilimsel tutumlarının kalıcılığına olan etkisinin incelenmesi. Eğitim Fakültesi Dergisi, 18(2), 363-382.

Dinçel, E. (2006). Ergenlik dönemi gelişimsel ödevleri ve psikolojik problemler. Yüksek Lisans Tezi, Ankara Üniversitesi, Sosyal Bilimler Enstitüsü, Ankara.

Dölek, N. (2002). Öğrencilerde zorbaca davranışların araştırılması ve bir önleyici program modeli. Yayınlanmamış Doktora Tezi, Marmara Üniversitesi, İstanbul.

Düzgün, Ş. (1995), Lise öğrencilerinin psikolojik belirtileri ile ana baba tutumlar arasındaki ilişkiler. Yayınlanmamış Doktora Tezi, Atatürk Üniversitesi, Sosyal Bilimler Enstitüsü, Erzurum.

Eskin, M., Ertekin, K., Harlak, H. ve Dereboy, Ç. (2008). Lise öğrencisi ergenlerde depresyonun yaygınlığı ve ilişkili olduğu etmenler. Türk Psikiyatri Dergisi, 19(4), 382-389.

Eşici, H. (2007). İlköğretim yedinci sınıf öğrencilerinin temel ihtiyaçlarının karşılanma düzeyi ile zorbacı davranışları arasındaki ilişki. Yüksek Lisans Tezi, Gazi Üniversitesi, Eğitim Bilimleri Enstitüsü, Ankara.

Genç, G. (2007). Genel liselerde akran zorbalı̆̆ ve yönetimi. Yayımlanmamış Doktora Tezi, İnönü Üniversitesi, Sosyal Bilimler Enstitüsü, Malatya.

Gençtan, E. (2016). İnsan olmak. İstanbul: Metis Yayınları.

Gökgöz, E. A. (2014). Okul eğitiminin kalitesini arttırmada okul-aile işbirliği ve okul sosyal hizmeti. Yayımlanmamış Yüksek Lisans Tezi, Yalova Üniversitesi, Sosyal Bilimler Enstitüsü, Yalova.

Gökler, R. (2007). Ilköğretim öğrencilerinde akran zorbalı̆ııın bazı değişkenler açısından incelenmesi. Yayınlanmamış Doktora Tezi, Ankara Üniversitesi Eğitim Bilimleri Enstitüsü, Ankara.

Gökler, R. (2009). Okullarda akran zorbalığı. Uluslararası İnsan Bilimleri Dergisi, 6(2), 511-537.

http://www.kidsareworthit.com/services.html, 12.12.2017. tarihinde erişilmiştir.

Huggins, M. (2016). Stigma is the origin of bullying. Journal of Catholic Education. 19 (3), 165-196. 12.20.2017 tarihinde http://dx.doi.org/10.15365/joce.1903092016 adresinden erişildi. 
Isernhagen, J. ve Harris, S. (2002). A comparison of 9th and 10th grade boys' and girls' bullying behaviors in two states. Educational Resources Information Center (ERIC), 2(2), 1-28.

İrfaner, S. (2009). Öğrenciler arasında gerçekleşen zorbalık eylemleri ve zorbalık konusunda öğrencilerin, öğretmenlerin ve okul yöneticilerinin tutum ve görüşleri. Yayımlanmamış Doktora Tezi, Hacettepe Üniversitesi, Sosyal Bilimler Enstitüsü, Ankara.

Kaya, F. (2009). Lise öğrencilerinde saldırgan davranışların ortaya çıkışına katkıda bulunan faktörlerin araştırılması. Yüksek Lisans Tezi, İstanbul Üniversitesi, Sağlık Bilimleri Enstitüsü, İstanbul.

Kılıç, N. (2009). İlköğretim 6, 7, 8. sinıf öğrencilerinin zorbalık düzeylerinin yordanması:Konya İli Cihanbeyli İlçesi merkez örneği. Yayımlanmamış Yüksek Lisans Tezi, Gaziantep Üniversitesi, Eğitim Bilimleri Enstitüsü, Ankara.

Kulaksızoğlu, A. (2017). Ergenlik psikolojisi. İstanbul: Remzi Kitabevi.

Kurt, K. (2015). Duygu ve davranışlarımızın patronu olmak. İstanbul: Nörokey Yayınevi.

Olweus, D. ve Solberg, C. (2018). Bullying among children and young people Information and guidance for parents. https://www.bufdir.no/global/Bullying_among_children_and_young_people.pdf, Erişim tarihi: 09.05.2018.

Pekel-Uludağlı, N. ve Uçonak, Z. (2005). Akran zorbalığı gruplarında yalnızlık ve akademik başarı ile sosyometrik statüye göre zorba/kurban davranış türleri. Türk Psikoloji Dergisi, 20(56), 77-92.

Pişkin, M. (2002). Okul zorbalığı, tanımı, türleri, ilişkili olduğu faktörler ve alınabilecek önlemler. Kuram ve Uygulamada Ĕ̆itim Bilimleri, 2, 531562.

Polat-Külcü, D. (2015). Çocuklarda Akran zorbalı̆̆ı ve benlik saygısının incelenmesi. Yayınlanmamış Yüksek Lisans Tezi, Mersin Üniversitesi, Sağlık Bilimleri Enstitüsü, Mersin.

Rigby, K. ve Slee, P. T. (1991). Bullying among Australian school children: Reported behavior and attitudes toward victims. The Journal of Social Psychology,13(5), 615-627.

Rigby, K. (2007). Bullying in schools: And what to do about it. Australia: ACER press.

Rigby, K. (2003). Consequences of bullying in school. Canada Journal Psychiatry, 48(9), 583-590. 
Salmivall, C. (2002). Is there an age decline in victimization by peers at school? Educational Research, 44(3), 269-277.

Sarıtaş, M. (2006). İlköğretim 7. ve 8. sinıf öğrencilerinde gözlenen zorba davranışların aile sorunlarına göre incelenmesi. Yayımlanmamış Yüksek Lisans Tezi, Karadeniz Teknik Üniversitesi, Trabzon.

Satan, A. (2006). ilköğretim ikinci kademe öğrencilerinin zorba davranış eğilimlerinin okul türü ve bazı sosyo demografik değişkenler ile ilişkisi. Doktora Tezi, Marmara Üniversitesi, Eğitim Bilimleri Enstitüsü, İstanbul.

Satan, A. (2011). Okulda zorbalığın aktörleri. Turan Stratejik Araştırmalar Merkezi Dergisi, 3(10), 55-66. 11.12.2017 tarihinde http://www.turansam.org adresinden erişilmiştir.

Sezer, Ö. (2010). Ergenlerin kendilik algilarının anne baba tutumları ve bazı faktörlerle ilişkisi. Yüzüncü Yal Üniversitesi, Eğitim Fakültesi Dergisi, 2(1), 1-19. 10.12.2017. tarihinde http://efdergi.yyu.edu.tr adresinden erişilmiştir.

Steinberg, L. (2007). Ergenlik, (F. Çok hzrl.), İstanbul: İmge Kitabevi.

Sutton, J., Smith, P. K. ve Swettenham, J. (1999). Social cognition and bullying: Social inadequacy or skilled manipulation? British Journal of Developmental Psychology, 17, 435-450.

Tamer, N. (2014). Ergenlerin teknolojik zorbalık alguları ve buna yönelik teknolojik zorbalık farkındalığı eğitimi: Pilot uygulama. Yayınlanmamış Yüksek Lisans Tezi. Bahçeşehir Üniversitesi, Eğitim Bilimleri Enstitüsü, İstanbul.

Tıpırdamaz-Sipahi, H. (2008). İzmir İli Bornova İlçesinde ilköğretim 6. ve 7. sınıf öğrencilerinde akran zorbalığı, etkileyen ve eşlik eden faktörler. Yayımlanmamış Doktora Tezi, Ege Üniversitesi, Sağlık Bilimleri Enstitüsü, İzmir.

Türk Dil Kurumu, (10.20.2017).

Türktan, Ş. (2013). Zorbalıkla başetmeye yönelik akran destek programının ortaokul 6. ve 7. sinıf öğrencilerinin zorbalıkla baş etme becerilerine etkileri. Yayınlanmamış Doktora Tezi, Eğitim Bilimleri Enstitüsü, Anadolu Üniversitesi, Eskişehir.

UNICEF, (2015). Investigating the prevalence and impact of peer abuse (bullying) on the development of Jamaica's children report.

Uysal, A. (2003). Şiddet karşıtı programlı eğitimin öğrencilerin çatışma çözümleri, şiddet eğilimleri ve davranışlarına yansıması. Yayınlanmamış Doktora Tezi, Ege Üniversitesi, Sağlık Bilimleri Enstitüsü, İzmir. 
Wang, J., Ronald, J. L. ve Nansel, T. R. (2009). Scholl bullying among adolescents in the United States: Physical, verbal, relational, and cyber, national institues of health. Journal of Adolescent Health, 45, 368-375.

Webb, N. B. (2017). (H. Sakarya Çev.)Çocuklarla sosyal hizmet uygulaması. içinde (s.426), Ankara:Nika yayınevi.

Wei, H. ve Williams, J. H. (2004). Relationship Between Peer Victimization and School Adjustment in Sixth-Grade Students:Investigation Mediation Effects. Violence and Victims, 19(5), 557-572.

Yalom, I. D. ve Steiner, H. (Ed.). (2007). Okul çă̆ı çocuklarının terapisi. (Y.Ö.Şallı Çev.), İstanbul:Prestij Yayınları.

Yaman, E., Eroğlu, Y. ve Peker, A. (2011). Başaçıkma stratejileriyle okul zorbalığı ve siber zorbalı. İstanbul: Kaknüs yayınları.

Yaman, Ö. M. (2016). Apaçi gençlik-gençlerin toplumsal davranış ve yönelimleri: İstanbul'da "apaçi" altkültür grupları üzerine nitel bir çalışma. İstanbul: Bir Yayıncilık.

Yavuzer, H. (2016a). Eğitim ve gelişim özellikleriyle okul çağı çocuğu. İstanbul: Remzi Kitabevi.

Yavuzer, H. (2016b). Çocuk ve suç. İstanbul: Remzi Kitabevi.

Yurttaş, A. (2010). İköğretim ikinci kademe öğrencilerinin zorbalık eğilimleri ile alglladıkları anne baba tutumlar arasındaki ilişkinin incelenmesi:İstanbul ili Kadıköy ilçesi örneği. Yayınlanmamış Yüksek Lisans Tezi, Yeditepe Üniversitesi, İstanbul.

Zaklama, C. (2003). The bullying spectrum in grade schools: Parents, teachers, child bullies and their victims. Yayımlanmamış Yüksek Lisans Tezi, McGill University, Montreal, Canada.

\section{Kaynakça Bilgisi / Citation Information}

Yelboğa, N. ve Koçak, O. (2019). Ergenlerde akran zorbalığını yordayan bazı faktörlerin zorba ve mağdur bireyler açısından değerlendirilmesi. OPUS-Uluslararası Toplum Araştırmaları Dergisi, 13(19), 2286-2320. DOI: 10.26466/opus.543567 